\title{
Psychrotrophic properties, toxigenic characteristics, and PFGE profiles of Bacillus cereus isolated from different foods and spices
}

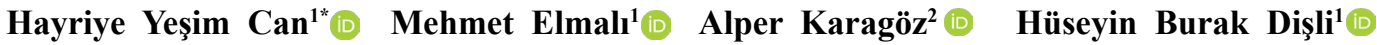

${ }^{1}$ Department of Food Hygiene and Technology, Faculty of Veterinary Medicine, Hatay Mustafa Kemal University, 31060, Hatay, Turkey. E-mail: yesimcan@mku.edu.tr. ${ }^{*}$ Corresponding author.

${ }^{2}$ Department of Molecular Biology and Genetics, Faculty of Science and Literature, Uşak University, Uşak, Turkey.

ABSTRACT: Bacillus cereus is an aerobic and facultatively anaerobic, spore-forming bacterium, and it is found naturally in soil and poses a risk factor for the contamination of food and foodstuffs including cereals, vegetables, spices, ready-to-eat (RTE) foods, meats, milk, and dairy products. This study determined the prevalence of B. cereus in raw poultry meat, raw cow's milk, cheese, spices, and RTE foods in Hatay province. The study also analysed the psychrotrophic properties, toxigenic characteristics, and pulsed-field gel electrophoresis (PFGE) profiles of the isolates. The levels of contamination with B. cereus determined for cheese, raw milk, RTE foods, spices, and raw poultry meat were $16.6 \%, 34.2 \%, 42.8 \%, 49 \%$, and $55.5 \%$, respectively. B. cereus was isolated from $84(42 \%)$ of the 200 samples analysed and the 84 isolates were verified by PCR analysis targeting the haemolysin gene specific for B. cereus. Of the total isolates, 64 (76.1\%) were psychrotrophic. The toxin gene profiling of $B$. cereus isolates was determined by amplifying the four genes $n h e, h b l$, cytK, and ces. The nhe and cytK genes were most frequently detected in the isolates, while the hbl and ces genes were not found. In addition, a high genetic relationship between the isolates was detected at a 92\% similarity level by PFGE analysis. In conclusion, the occurrence of both psychrotrophic and toxigenic B. cereus strains in this study indicated a potential risk for food spoilage and food poisoning.

Key words: Bacillus cereus, food poisoning, PCR, PFGE typing, toxin gene.

Propriedades psicrotróficas, características toxigênicas e perfis PFGE de Bacillus cereus isolado de diferentes alimentos e especiarias

RESUMO: Bacillus cereus é uma bactéria formadora de esporos aeróbica e facultativamente anaeróbica, encontrada naturalmente no solo e representa um fator de risco para a contaminação de alimentos e alimentos, incluindo cereais, vegetais, especiarias, alimentos prontos para comer (RTE), carnes, leite e laticinios. Este estudo teve como objetivo determinar a prevalência de B. cereus em carne crua de aves, leite de vaca cru, queijo, especiarias e alimentos RTE na província de Hatay. O estudo também analisou as propriedades psicrotróficas, características toxigenicas e perfis de PFGE dos isolados. Os niveis de contaminação com B. cereus determinados para queijo, leite cru, alimentos RTE, especiarias e carne de frango crua foram de 16,6\%, 34,2\%, 42,8\%, 49\% e 55,5\%, respectivamente. B. cereus foi isolado de 84 (42\%) das 200 amostras analisadas e os 84 isolados foram verificados por análise de PCR visando o gene da hemolisina especifico para B. cereus. Do total de isolados, 64 (76,1\%) eram psicrotróficos. O perfil do gene da toxina de isolados de B. cereus foi determinado pela amplificação dos quatro genes nhe, $h b l$, cytK e ces. Os genes nhe e cytK foram detectados com maior frequência nos isolados, enquanto os genes hbl e ces não foram encontrados. Além disso, uma alta relação genética entre os isolados foi detectada em um nível de similaridade de $92 \%$ pela análise de PFGE. Em conclusão, a ocorrência de cepas psicrotróficas e toxigênicas de B. cereus neste estudo indica um risco potencial de deterioração e intoxicação alimentar.

Palavras-chave: Bacillus cereus, intoxicação alimentar, PCR, tipagem PFGE, gene da toxina.

\section{INTRODUCTION}

Bacillus cereus is one of the major foodborne pathogenic bacteria that causes two types of food poisoning. The first, emetic syndrome, is characterised by nausea and vomiting and occurs within a few hours of consumption of contaminated food. Emetic syndrome is caused by a toxin called cereulide, a heat-stable peptide synthesised in the food. The second, diarrhoeal syndrome, is characterised by abdominal pain and diarrhoea. Diarrhoea is associated with some enterotoxins, the haemolysin $\mathrm{BL}$ (HBL), the non-haemolytic enterotoxin (NHE), and the cytotoxin K (CYTK). Diarrhoeal toxins are sensitive to heat and are synthesised during the vegetative growth of Bacillus 
cereus in the small intestine. These enterotoxins are particularly important in the virulence mechanism of $B$. cereus and are encoded by the three genes $h b l$, nhe, and $c y t K$, respectively. There are also reports that the enterotoxin genes are more commonly found in $B$. cereus strains than the emetic gene (GRANUM \& LUND, 1997; STENFORS ARNESEN et al., 2008; HARIRAM \& LABBE, 2015; TEWARI et al., 2015; OWUSU-KWARTENG et al., 2017; FOGELE et al., 2018; GAO et al., 2018; BERTHOLD-PLUTA et al., 2019; SÁNCHEZ-CHICA et al., 2020b). At the same time, B. cereus can cause serious extraintestinal diseases such as bacteraemia, meningitis, arthritis, and endocarditis (LIU et al., 2016; YU et al., 2020), that need to be taken into consideration as well as food intoxication.

B. cereus is generally known as a mesophilic microorganism, which has optimal growth between 35 and $40{ }^{\circ} \mathrm{C}$. However, increasing numbers of psychrotrophic $B$. cereus strains described can grow at refrigerator temperatures and are responsible from the microbial spoilage of refrigerated foods (GRANUM \& LUND, 1997; MC KILLIP, 2000; WIJNANDS et al., 2006; STENFORS ARNESEN et al., 2008; PRETORIUS \& BUYS, 2021). Until now, $B$. cereus has been isolated from different kinds of foods and foodstuffs such as meats, milk and dairy products, fish and seafood products, rice, starch, flours, spices and herbs, vegetables, ready-to-eat (RTE) foods, powdered foods (infant formula, powdered milk), and pastry (WIJNANDS et al., 2006; PARK et al., 2009; CADIRCI et al., 2013; HARIRAM \& LABBE, 2015; TEWARI et al., 2015; OWUSU-KWARTENG et al., 2017; YIBAR et al., 2017; FOGELE et al., 2018; GAO et al., 2018; GDOURA-BEN AMOR et al., 2018; OSMAN et al., 2018; BERTHOLD-PLUTA et al., 2019; ADAME-GÓMEZ et al., 2020; SÁNCHEZCHICA et al., 2020a; SÁNCHEZ-CHICA et al., $2020 \mathrm{~b})$. The diarrhoeal disease is usually associated with proteinaceous foods, while the emetic type is more commonly due to the consumption of starchrich foods (AGATA et al., 2002; STENFORS ARNESEN et al., 2008).

Considering that food safety is an important public health concern and consumption of foods contaminated with $B$. cereus can cause food intoxication, we investigated the prevalence of $B$. cereus in different foods and spices, which are very popular, traditional and often consumed by local people in Hatay province. B. cereus isolates were further analysed for their ability to grow at $7{ }^{\circ} \mathrm{C}$, and the presence of toxin genes. Besides, PFGE analysis was carried out to evaluate the genetic relatedness of isolates.

\section{MATERIALS AND METHODS}

Samples

In Hatay, the southeastern province of Turkey, 45 raw poultry meat, 35 raw cow's milk, 30 cheese samples, 55 spices, and 35 ready-to-eat (RTE) foods were randomly collected from December 2018 to February 2020 and transported to the laboratory under cold chain conditions.

The spice samples were dried, powdered, and unpackaged and included thyme, mint, cumin, black pepper, red pepper, ginger, and sumac. The RTE foods included: Abagannus (a kind of salad prepared from roasted eggplant, roasted paprika, roasted tomato, pomegranate juice, garlic, olive oil, and salt), humus (hummus means chickpea in Arabic, and is made from chickpeas, sesame paste, lemon juice, garlic, salt, cumin, and olive oil), Muhammara (prepared for breakfast from walnut paste, tomato paste, spices, and olive oil), haydari (a kind of appetiser made from strained yogurt, mint, and dill), and olive salad (prepared for breakfast and made from green olives without seeds, parsley, tomatoes, green onions, olive oil, pomegranate juice, and red peppers). The cheese samples included traditional cheeses such as Sürk and Carra that are frequently consumed in Hatay province. They are both produced with spices or herbs. Carra cheese is made by mixing white cheese (manufactured from raw goat's milk or cow's milk) and Cokelek (cheese produced by heattreating yogurt). Black cumin or thyme is added to the cheese. Sürk cheese is also made from Cokelek and thyme, cumin, mint, cinnamon, black peppers, ginger, and red peppers are used in its production.

\section{Reference strain}

Lyophilised Bacillus cereus strain was obtained from the National Type Culture Collection Laboratory, General Directorate of Public Health, Turkey, and used as a positive control in microbiological and molecular analysis.

\section{Isolation and identification \\ The conventional culture method} (TALLENT et al., 2012) and PCR technique were used in the isolation and identification of B. cereus. For the selective and pre-enrichment stages, $90 \mathrm{~mL}$ of Tripticase Soy Broth supplemented with polymyxin B $(10 \mathrm{mg} / \mathrm{mL})$ was added to each sample and they were 
homogenised. Then, the mixtures were incubated for $24 \mathrm{~h}$ at $30^{\circ} \mathrm{C}$. A loopful of each selective broth was taken, plated onto Chromogenic Bacillus cereus Agar (Oxoid CM1036) mixed with Brilliance Bacillus cereus Selective Supplement (Oxoid SR0230), and incubated at $30{ }^{\circ} \mathrm{C}$ under aerobic conditions. After 24 -48 hours of incubation, all the suspicious blue/green colonies of $B$. cereus were taken and stored at $-20{ }^{\circ} \mathrm{C}$ for molecular and toxin gene analysis.

\section{Molecular analysis}

For the molecular identification, all the presumptive $B$. cereus isolates were confirmed by the PCR technique based on the detection of the haemolysin gene. Genomic DNA was extracted using a GF-1 Nucleic Acid Extraction Kit (Vivantis, Malaysia) from the overnight Brain-Heart Infusion broth (Oxoid) cultures. DNA extraction was done according to the manufacturer's instructions. Specific primer pairs and thermal cycling conditions described by WANG et al. (1997) were used in this study. The PCR amplicons were controlled in gel electrophoresis $(1.5 \%)$ carried out at $100 \mathrm{~V}$ for 50 min (CS-300V, England). The gels were stained with Safe View (Abm G108) and visualised with a UV transilluminator (UVP, USA).

\section{Toxin gene analysis}

The toxin genes ( $h b l$, nhe, cytK, ces) of $B$. cereus isolates were detected with a multiplex PCR. In the present study, hbl, nhe, cytK, and ces genes were searched using the following primers: (hblF, 5'-GTAAATTAIGATGAICAATTTC-3'; hblR, 5'-AGAATA GGCATTCATAGATT-3') (nheF, 5'-AAGCIGCTCTTCGIATTC-3'; nheR, 5' -ITIGTTGAAATAAGCTGTGG-3') (cytKF, 5' -ACAGATATCGGICAAAATGC-3'; cytKR, 5' -CAAGTIACTTGACCIGTTGC-3') (cesF, 5'-GGTGACACATTATCATATAAGGTG-3', cesR, 5'-GTAAGCGAACCTGTCTGTAACAACA-3') (Ella Biotech) (EHLING-SCHULZ et al., 2005; EHLING-SCHULZ et al., 2006). The reaction mixture for multiplex PCR and amplification protocol was produced according to EHLINGSCHULZ et al. (2006).

\section{Psychrotrophic property analysis}

To detect the psychrotrophic properties of $B$. cereus, all isolates were subcultured in BrainHeart Infusion broth and incubated for $24 \mathrm{~h}$ at $30^{\circ} \mathrm{C}$. Then, they were streaked on Tryptone Soya Agar. Plates were placed in a refrigerated incubator and the temperature was set at $7{ }^{\circ} \mathrm{C}$. Plates were checked for bacterial growth after incubation periods of 24,48 , 72 , and 168 hours.

\section{Pulsed-field gel electrophoresis (PFGE) analysis}

To better understand the genetic relationship between $B$. cereus strains, PFGE was performed according to LIU et al. (2016) using the SmaI macrorestriction enzyme. The 84 B. cereus isolates were first subjected to a cell lysis process to extract DNA. Then, genomic DNAs of the isolates were digested with SmaI (Takara, Japan) restriction enzyme. Following enzymatic digestion, they were subjected to electrophoresis in a CHEF-DR II system (Bio-Rad, Belgium). Then, electrophoretic bands were analysed under UV using a gel documentation system (Gel Doc, Bio-Rad, Belgium). The Bionumerics 5.10 software programme was used for dendrogram analysis, and the dendrogram was created using Dice coefficients. A similarity value was selected as $85 \%$ to reveal the genetic relationship of isolates.

\section{RESULTS AND DISCUSSION}

Prevalence and psychrotrophic properties of Bacillus cereus

In the present study, $84 \mathrm{~B}$. cereus isolates were recovered from 200 samples. High prevalence of B. cereus isolates was detected in poultry meat $(25 / 45$, $55.5 \%)$, followed by spices $(27 / 55,49 \%)$, RTE $(15 / 35$, $42.8 \%)$, raw milk $(12 / 35,34.2 \%)$, and cheese $(5 / 30$, $16.6 \%$ ). Therefore, 84 isolates were molecularly confirmed as $B$. cereus by the amplification of the haemolysin gene (Figure 1). Sixty-four (76.1\%) of the isolates had psychrotrophic abilities. All the isolated strains of poultry meat (100\%) and eight of $15(53.3 \%)$, eight of $12(66.6 \%), 19$ of $27(70.3 \%)$, and four of five $(80 \%)$ isolates recovered from RTE, milk, spices, and cheese, respectively, were able to grow at $7{ }^{\circ} \mathrm{C}$ (Table 1, 2 and 3 ).

The overall prevalence of $B$. cereus was $42 \%$ in this study. Compared to our data, different results have previously been reported as $30.9 \%$ by TEWARI et al. (2015), $40.4 \%$ by OWUSU-KWARTENG et al. (2017), 25.3\% by GDOURA-BEN AMOR et al. (2018), 27\% by GAO et al. (2018), 29.4\% by ADAME-GÓMEZ et al. (2020), and $11 \%$ by SÁNCHEZ-CHICA et al. (2020b) in various foods in other countries. When comparing the results with other studies by food type, the $B$. cereus group was isolated from chicken meat at 50\% (OSMAN et al., 2018), like this study (55.5\%). WIJNANDS et al. (2006) and GDOURA-BEN AMOR et al. (2018) detected $B$. 


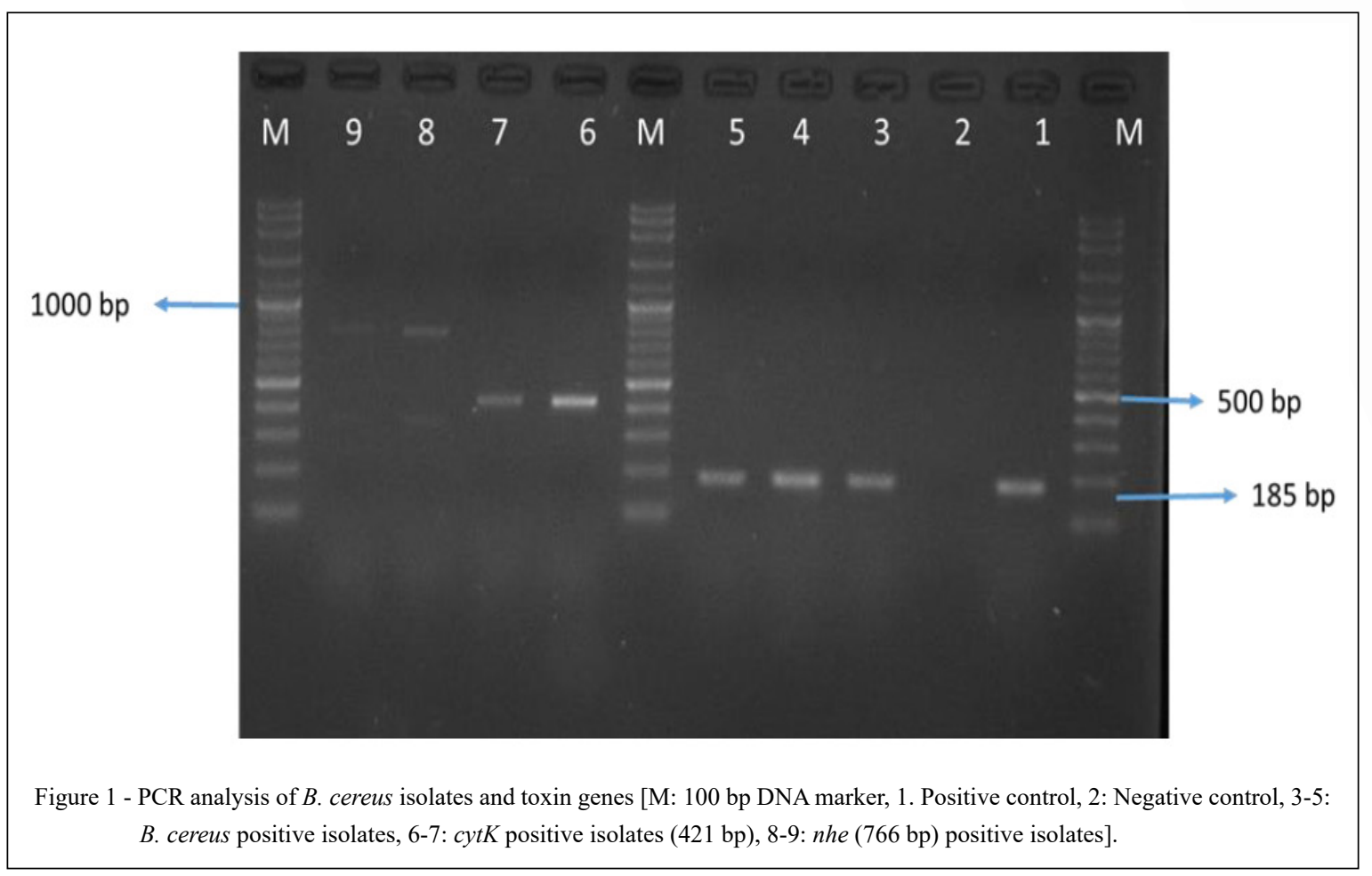

cereus in $3.0 \%$ vof meat and meat products, and $9.4 \%$ of raw poultry meat. Interestingly, GDOURABEN AMOR et al. (2018) and TEWARI et al. (2015) reported high incidence levels in cooked poultry compared to raw poultry samples. They explained this finding by the germination of $B$. cereus spores during inappropriate storage and the inadequate cooking of food.

Given that B. cereus is a common soil bacterium, it is often reported in milk. However, large numbers are needed in milk to cause intoxication and at this stage defects in milk are easily observed. In some dairy products, it is more difficult to observe spoilage and they pose a serious risk for Bacillus cereus food poisoning (STENFORS ARNESEN et al., 2008). For raw milk and dairy products, the prevalence of $B$. cereus in cheeses reported in this study was very similar to that reported by SÁNCHEZ-CHICA et al. (2020a) (19.6\%), whereas WIJNANDS et al. (2006) and YIBAR et al. (2017) reported a lower prevalence $(10 \%)$ in milk and milk products. Contrary to the above studies, BERTHOLD-PLUTA et al. (2019) detected B. cereus contamination in $41.7 \%$ of cheese samples.

In the studies of YIBAR et al. (2017), GAO et al. (2018), and BERTHOLD-PLUTA et al. (2019), the prevalence of $B$. cereus in pasteurised milk was reported as $30 \%, 27 \%$, and $26 \%$, respectively. This may be considered as higher contamination for pasteurised milk since heat treatment is applied to pasteurised milk. The authors suggested that low/inadequate pasteurisation or postpasteurisation contamination could be the reason. The heat-stable spores of $B$. cereus are a problem in milk and dairy products as they are not inactivated during the pasteurisation (BENAHMED et al., 2020; PRETORIUS \& BUYS, 2021). When comparing raw milk results, a lower incidence of $3.8 \%$ was reported by YIBAR et al. (2017). Contrarily, OWUSUKWARTENG et al. (2017) reported a relatively higher prevalence in raw milk (47\%), yogurt (35\%), and cheese (39\%). In addition, GUNDOGAN \& AVCI (2014) found that raw milk, cheese, and ice cream samples were contaminated with $B$. cereus at levels of $90 \%, 70 \%$, and $20 \%$, respectively. $B$. cereus has also been identified in $13 \%$ of powdered milk (SÁNCHEZ-CHICA et al., 2020b), and 30\% and $11 \%$ of infant formulas, respectively, in the studies of BERTHOLD-PLUTA et al. (2019), and SÁNCHEZ-CHICA et al. (2020b), and 7\% of dairy desserts (CADIRCI et al., 2013).

Regarding the contamination level in spices, AKSU et al. (2000) and BERTHOLD-PLUTA 
Table 1 - Psychrotrophic property, toxin gene, and PFGE profiles of B. cereus isolates.

\begin{tabular}{|c|c|c|c|c|c|c|c|c|}
\hline \multirow{2}{*}{ Isolate } & \multirow{2}{*}{-------Source-------- } & \multirow{2}{*}{-Psychrotrophic property- } & \multicolumn{4}{|c|}{------------Toxin gene----------- } & \multirow{2}{*}{-Toxin profile- } & \multirow{2}{*}{$\begin{array}{l}\text {---PFGE profile--- } \\
\text {-------SmaI-------- }\end{array}$} \\
\hline & & & $c y t K$ & nhe & $h b l$ & ces & & \\
\hline 1 & Raw poultry meat & + & + & - & - & - & $t_{1}$ & $\mathrm{~A}_{1}$ \\
\hline 2 & Raw poultry meat & + & - & + & - & - & $\mathrm{t}_{2}$ & $\mathrm{~A}_{1}$ \\
\hline 3 & Raw poultry meat & + & + & - & - & - & $t_{1}$ & $\mathrm{C}$ \\
\hline 4 & Raw poultry meat & + & + & - & - & - & $\mathrm{t}_{1}$ & $\mathrm{C}$ \\
\hline 5 & Raw poultry meat & + & + & - & - & - & $t_{1}$ & $\mathrm{C}$ \\
\hline 6 & Raw poultry meat & + & - & - & - & - & $t_{4}$ & $\mathrm{C}$ \\
\hline 7 & Raw poultry meat & + & - & + & - & - & $\mathrm{t}_{2}$ & $\mathrm{C}$ \\
\hline 8 & Raw poultry meat & + & + & - & - & - & $\mathrm{t}_{1}$ & $\mathrm{C}$ \\
\hline 9 & Raw poultry meat & + & + & + & - & - & $\mathrm{t}_{3}$ & $\mathrm{~A} 2$ \\
\hline 10 & Raw poultry meat & + & - & - & - & - & $t_{4}$ & $\mathrm{~A} 2$ \\
\hline 11 & Raw poultry meat & + & - & - & - & - & $\mathrm{t}_{4}$ & $\mathrm{~A} 2$ \\
\hline 12 & Raw poultry meat & + & - & - & - & - & $\mathrm{t}_{4}$ & $\mathrm{~A} 2$ \\
\hline 13 & Raw poultry meat & + & - & - & - & - & $\mathrm{t}_{4}$ & $\mathrm{~A} 2$ \\
\hline 14 & Raw poultry meat & + & - & - & - & - & $t_{4}$ & $\mathrm{C}$ \\
\hline 15 & Raw poultry meat & + & - & - & - & - & $\mathrm{t}_{4}$ & $\mathrm{C}$ \\
\hline 16 & Raw poultry meat & + & - & - & - & - & $\mathrm{t}_{4}$ & $\mathrm{C}$ \\
\hline 17 & Raw poultry meat & + & - & - & - & - & $\mathrm{t}_{4}$ & $\mathrm{C}$ \\
\hline 18 & Raw poultry meat & + & - & - & - & - & $\mathrm{t}_{4}$ & $\mathrm{C}$ \\
\hline 19 & Raw poultry meat & + & - & - & - & - & $\mathrm{t}_{4}$ & $\mathrm{C}$ \\
\hline 20 & Raw poultry meat & + & - & - & - & - & $\mathrm{t}_{4}$ & $\mathrm{C}$ \\
\hline 21 & Raw poultry meat & + & - & - & - & - & $\mathrm{t}_{4}$ & $\mathrm{C}$ \\
\hline 22 & Raw poultry meat & + & - & - & - & - & $\mathrm{t}_{4}$ & $\mathrm{C}$ \\
\hline 23 & Raw poultry meat & + & - & - & - & - & $\mathrm{t}_{4}$ & $\mathrm{C}$ \\
\hline 24 & Raw poultry meat & + & - & - & - & - & $\mathrm{t}_{4}$ & $\mathrm{C}$ \\
\hline 25 & Raw poultry meat & + & - & - & - & - & $\mathrm{t}_{4}$ & $\mathrm{C}$ \\
\hline 26 & Raw cow milk & - & - & - & - & - & $t_{4}$ & $\mathrm{C}$ \\
\hline 27 & Raw cow milk & + & - & - & - & - & $t_{4}$ & $\mathrm{C}$ \\
\hline 28 & Raw cow milk & - & - & - & - & - & $\mathrm{t}_{4}$ & $\mathrm{~B} 1$ \\
\hline 29 & Raw cow milk & + & - & - & - & - & $\mathrm{t}_{4}$ & $\mathrm{~B} 1$ \\
\hline 30 & Raw cow milk & + & - & - & - & - & $\mathrm{t}_{4}$ & B1 \\
\hline 31 & Raw cow milk & - & - & - & - & - & $\mathrm{t}_{4}$ & $\mathrm{C}$ \\
\hline 32 & Raw cow milk & + & - & - & - & - & $\mathrm{t}_{4}$ & $\mathrm{C}$ \\
\hline 33 & Raw cow milk & + & - & - & - & - & $\mathrm{t}_{4}$ & $\mathrm{C}$ \\
\hline 34 & Raw cow milk & - & - & - & - & - & $\mathrm{t}_{4}$ & $\mathrm{C}$ \\
\hline 35 & Raw cow milk & + & - & - & - & - & $t_{4}$ & $\mathrm{C}$ \\
\hline 36 & Raw cow milk & + & - & - & - & - & $\mathrm{t}_{4}$ & $\mathrm{C}$ \\
\hline 37 & Raw cow milk & + & - & - & - & - & $t_{4}$ & $\mathrm{C}$ \\
\hline
\end{tabular}

PFGE: pulsed-field gel electrophoresis; RTE: ready-to-eat; t: toxin profile; $\mathrm{t}_{1}: c y t K^{+}, n h e^{-}, h b l, c e s ; \mathrm{t}_{2}: c y t K^{-}, n h e^{+}, h b l^{\prime}, \operatorname{ces}^{-} ; \mathrm{t}_{3:}: c y t K^{+}$, $n h e^{+}, h b l, c e s ; t_{4}: c^{\prime} y t K^{-}, n h e^{-}, h b l$, ces $^{-}$. 
Table 2 - Psychrotrophic property, toxin gene, and PFGE profiles of B. cereus isolates.

\begin{tabular}{|c|c|c|c|c|c|c|c|c|}
\hline \multirow{2}{*}{ Isolate } & \multirow{2}{*}{--Source-- } & \multirow{2}{*}{--Psychrotrophic property-- } & \multicolumn{4}{|c|}{--------------Toxin gene-------------- } & \multirow[t]{2}{*}{--Toxin profile-- } & \multirow{2}{*}{$\begin{array}{l}\text {--PFGE profile-- } \\
\text {------SmaI------- }\end{array}$} \\
\hline & & & --cytk-- & --nhe-- & $--h b l--$ & -ces- & & \\
\hline 38 & Cheese & - & - & + & - & - & $\mathrm{t}_{2}$ & $\mathrm{C}$ \\
\hline 39 & Cheese & + & - & + & - & - & $\mathrm{t}_{2}$ & $\mathrm{C}$ \\
\hline 40 & Cheese & + & - & - & - & - & $\mathrm{t}_{4}$ & $\mathrm{C}$ \\
\hline 41 & Cheese & + & - & - & - & - & $\mathrm{t}_{4}$ & $\mathrm{C}$ \\
\hline 42 & Cheese & + & - & + & - & - & $\mathrm{t}_{2}$ & $\mathrm{C}$ \\
\hline 43 & Spices & - & - & - & - & - & $\mathrm{t}_{4}$ & $\mathrm{C}$ \\
\hline 44 & Spices & + & - & - & - & - & $\mathrm{t}_{4}$ & $\mathrm{C}$ \\
\hline 45 & Spices & + & - & - & - & - & $\mathrm{t}_{4}$ & $\mathrm{C}$ \\
\hline 46 & Spices & + & + & + & - & - & $\mathrm{t}_{3}$ & $\mathrm{C}$ \\
\hline 47 & Spices & + & + & - & - & - & $\mathrm{t}_{1}$ & $\mathrm{C}$ \\
\hline 48 & Spices & + & + & - & - & - & $\mathrm{t}_{1}$ & B2 \\
\hline 49 & Spices & + & - & - & - & - & $\mathrm{t}_{4}$ & $\mathrm{C}$ \\
\hline 50 & Spices & + & + & + & - & - & $t_{3}$ & $\mathrm{C}$ \\
\hline 51 & Spices & - & + & + & - & - & $\mathrm{t}_{3}$ & $\mathrm{C}$ \\
\hline 52 & Spices & - & + & + & - & - & $\mathrm{t}_{3}$ & $\mathrm{C}$ \\
\hline 53 & Spices & + & + & + & - & - & $\mathrm{t}_{3}$ & $\mathrm{C}$ \\
\hline 54 & Spices & + & - & - & - & - & $\mathrm{t}_{4}$ & $\mathrm{C}$ \\
\hline 55 & Spices & + & + & + & - & - & $\mathrm{t}_{3}$ & $\mathrm{C}$ \\
\hline 56 & Spices & + & - & - & - & - & $\mathrm{t}_{4}$ & $\mathrm{C}$ \\
\hline 57 & Spices & + & + & + & - & - & $t_{3}$ & $\mathrm{C}$ \\
\hline 58 & Spices & - & - & + & - & - & $\mathrm{t}_{2}$ & $\mathrm{C}$ \\
\hline 59 & Spices & - & + & - & - & - & $\mathrm{t}_{1}$ & B1 \\
\hline 60 & Spices & - & + & - & - & - & $\mathrm{t}_{1}$ & B1 \\
\hline 61 & Spices & - & + & + & - & - & $\mathrm{t}_{3}$ & B1 \\
\hline 62 & Spices & + & - & + & - & - & $\mathrm{t}_{2}$ & B1 \\
\hline 63 & Spices & + & + & + & - & - & $t_{3}$ & $\mathrm{~A} 2$ \\
\hline 64 & Spices & + & + & + & - & - & $\mathrm{t}_{3}$ & A2 \\
\hline 65 & Spices & + & - & - & - & - & $\mathrm{t}_{4}$ & $\mathrm{~A} 2$ \\
\hline 66 & Spices & + & - & + & - & - & $\mathrm{t}_{2}$ & A2 \\
\hline 67 & Spices & + & + & + & - & - & $\mathrm{t}_{3}$ & A2 \\
\hline 68 & Spices & - & + & + & - & - & $\mathrm{t}_{3}$ & $\mathrm{~A} 2$ \\
\hline 69 & Spices & + & - & + & - & - & $\mathrm{t}_{2}$ & $\mathrm{~A} 2$ \\
\hline 70 & RTE & - & - & - & - & - & $\mathrm{t}_{4}$ & $\mathrm{C}$ \\
\hline 71 & RTE & - & + & + & - & - & $\mathrm{t}_{3}$ & $\mathrm{C}$ \\
\hline 72 & RTE & + & + & + & - & - & $t_{3}$ & $\mathrm{C}$ \\
\hline
\end{tabular}

PFGE: pulsed-field gel electrophoresis; RTE: ready-to-eat; t: toxin profile; $\mathrm{t}_{1}: c y t K^{+}, n h e^{-}, h b l^{-}, c e s ; \mathrm{t}_{2}: c y t K^{-}, n h e^{+}, h b l^{-}, c e s^{-} ; \mathrm{t}_{3}: c y t K^{+}$,

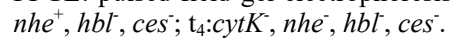


Table 3 - Psychrotrophic property, toxin gene, and PFGE profiles of B. cereus isolates.

\begin{tabular}{|c|c|c|c|c|c|c|c|c|}
\hline \multirow{2}{*}{ Isolate } & \multirow{2}{*}{--Source-- } & \multirow{2}{*}{-Psychrotrophic property- } & \multicolumn{4}{|c|}{ 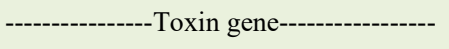 } & \multirow[t]{2}{*}{-Toxin profile- } & \multirow{2}{*}{$\begin{array}{l}\text {-PFGE profile- } \\
\text {------SmaI------ }\end{array}$} \\
\hline & & & --cytk-- & --nhe-- & --hbl-- & -ces- & & \\
\hline 73 & RTE & + & - & - & - & - & $\mathrm{t}_{4}$ & $\mathrm{C}$ \\
\hline 74 & RTE & + & - & + & - & - & $\mathrm{t}_{2}$ & $\mathrm{C}$ \\
\hline 75 & RTE & + & - & + & - & - & $\mathrm{t}_{2}$ & $\mathrm{C}$ \\
\hline 76 & RTE & + & - & - & - & - & $\mathrm{t}_{4}$ & $\mathrm{C}$ \\
\hline 77 & RTE & - & - & - & - & - & $\mathrm{t}_{4}$ & $\mathrm{C}$ \\
\hline 78 & RTE & - & - & - & - & - & $\mathrm{t}_{4}$ & $\mathrm{C}$ \\
\hline 79 & RTE & - & - & - & - & - & $\mathrm{t}_{4}$ & $\mathrm{C}$ \\
\hline 80 & RTE & - & - & - & - & - & $\mathrm{t}_{4}$ & $\mathrm{C}$ \\
\hline 81 & RTE & + & - & - & - & - & $\mathrm{t}_{4}$ & $\mathrm{C}$ \\
\hline 82 & RTE & + & - & - & - & - & $\mathrm{t}_{4}$ & $\mathrm{C}$ \\
\hline 83 & RTE & + & - & - & - & - & $\mathrm{t}_{4}$ & $\mathrm{C}$ \\
\hline 84 & RTE & - & - & - & - & - & $t_{4}$ & $\mathrm{C}$ \\
\hline
\end{tabular}

PFGE: pulsed-field gel electrophoresis; RTE: ready-to-eat; t: toxin profile; $\mathrm{t}_{1}: c y t K^{+}, n h e^{-}, h b l^{-}, c e s-\mathrm{t}_{2}: c y t K^{-}, n h e^{+}, h b l^{-}, c e s^{-} ; \mathrm{t}_{3}: c y t K^{+}$, $n h e^{+}, h b l$, ces; $\mathrm{t}_{4}:$ cytK $^{-}$, nhe $e^{-}, h b l^{-}$, ces $^{-}$.

et al. (2019) reported that the incidence of $B$. cereus in herbs and spices was $63 \%$, with counts ranging from 2.0 to $\log 3.0 \log \mathrm{cfu} / \mathrm{g}$. In our study, the prevalence of $B$. cereus in spices was relatively high (49\%) compared to the studies of GDOURA-BEN AMOR et al. (2018) and HARIRAM \& LABBE (2015) with $28.8 \%$ and $31 \%$, respectively, whereas FOGELE et al. (2018) reported a higher prevalence $(76 \%)$ in spices. However, WIJNANDS et al. (2006) isolated $B$. cereus from $11.5 \%$ of flavourings in the Netherlands. Since $B$. cereus is a spore-forming and common soil microorganism, it could be difficult to eliminate this bacterium from food processing plants and the environment. In another context, PARK et al. (2009) found that $25 \%$ of cereal samples were positive for $B$. cereus in Korea. High contamination levels (56.7\%) have also been reported in coffee samples by SOUZA \& ABRANTES (2011). These results demonstrated that a higher prevalence in spices is possible due to the occurrence of this bacterium in soil and plants (GRANUM \& LUND, 1997; STENFORS ARNESEN et al., 2008; BERTHOLD-PLUTA et al., 2019). As spices are often used as aromatic and flavour components in many types of foods (WIJNANDS et al. 2006; HARIRAM \& LABBE 2015; FOGELE et al., 2018), this can be a potential risk for the crosscontamination of some food products, such as RTE foods, because they are not subjected to further heat treatment before consumption (BERTHOLDPLUTA et al. 2019). In this sense, it is essential to ensure the microbial safety of spices. As other researchers have recommended (AKSU et al. 2000; FOGELE et al., 2018), we suggested sterilisation and the hygienic and adequate packaging of spices.

RTE foods such as Abagannus, humus, haydari, muhammara, and olive salad are very popular and commonly consumed in Hatay province, but they may pose a potential risk for $B$. cereus contamination as they are prepared without any heat treatment and consumed directly. In this study, $15(42.8 \%)$ out of 35 RTE samples were found to contain $B$. cereus, consistent with other studies where $B$. cereus prevalence in RTE foods was reported as $48.2 \%$ by WIJNANDS et al. (2006) and $35 \%$ by YU et al. (2020). The majority (76.1\%) of our isolates were psychrotrophic, which means that they can grow slightly during refrigeration storage and can cause spoilage in refrigerated foods. Unlike our results, WIJNANDS et al. (2006) determined that the minority of their isolates (4.4\%) were psychrotrophic using the PCR method while most of them were mesophilic. However, ADAME-GÓMEZ et al. (2020) reported that almost all their isolates (91.3\%) were psychrophilic. Also, BERTHOLD-PLUTA et al. (2019) reported that $25 \%$ of their isolates could grow at $7{ }^{\circ} \mathrm{C}$. In this respect, the presence of psychrotropic 
B. cereus strains in various food products cannot be ignored since they have a significant effect especially on the quality and shelf life of refrigerated foods.

\section{Detection of toxin genes by multiplex PCR}

We found that $41.6 \%$ of our isolates harboured toxin genes while the remainder had none. The genes cytK and nhe were commonly detected in the isolates alone or together, but the other enterotoxin encoding gene, $h b l$, and emetic gene (ces) were not determined in this study (Table 1, 2 and 3).

According to the presence of toxin genes, four toxin gene profiles $\left(\mathrm{t}_{1}\right.$; toxin profile $1, \mathrm{t}_{2}$; toxin profile $2, \mathrm{t}_{3 ;}$ toxin profile 3 , and $\mathrm{t}_{4}$ toxin profile 4 ) were detected in the study. Nine (10.7\%), $11(13 \%), 15(17.8 \%)$, and 49 (58.3) isolates belonged to $\mathrm{t}_{1}\left(c y t K^{+}, n h e^{-}, h b l, c e s^{-}\right), \mathrm{t}_{2}$ $\left(c y t K^{-}, n h e^{+}, h b l^{-}, c e s^{-}\right), \mathrm{t}_{3}\left(c y t K^{+}, n h e^{+}, h b l, c e s\right)$, and $\mathrm{t}_{4}$ $\left(c^{\prime} \mathrm{K}^{-}, n h e^{-}, h b l, \mathrm{ces}^{-}\right)$, respectively. The most prevalent toxin profile among the enterotoxigenic isolates was $\mathrm{t}_{3}$, including both $c y t K$ and nhe genes.

When reviewing studies performed in Turkey and elsewhere (PARK et al., 2009; CADIRCI et al. 2013; HARIRAM \& LABBE, 2015; TEWARI et al., 2015; OWUSU-KWARTENG et al., 2017; WALKER YORK MOORE et al., 2017; YIBAR et al., 2017; FOGELE et al., 2018; OSMAN et al., 2018; ADAME-GÓMEZ et al., 2020; SÁNCHEZCHICA et al., 2020a; SÁNCHEZ-CHICA et al., 2020b; YU et al., 2020), enterotoxin genes were more frequently found than the emetic gene, indicating that diarrhoeal strains have a widespread distribution, consistent with this study. However, we did not identify any emetic strain since all the isolates lacked the ces gene, like the findings of HARIRAM \& LABBE (2015), FOGELE et al. (2018), ADAMEGÓMEZ et al. (2020), SÁNCHEZ-CHICA et al. (2020a), and SÁNCHEZ-CHICA et al. (2020b).

On the contrary, in the studies of BERTHOLD-PLUTA et al. (2019), GAO et al. (2018), OWUSU-KWARTENG et al. (2017), and YU et al. (2020), the ces gene was detected but it was the least frequently observed toxin gene, reported in only $9 \%, 7 \%, 5 \%$, and $1.2 \%$ of $B$. cereus strains, respectively. Also, WIJNANDS et al. (2006) found the gene responsible for cereulidelike toxin production in $8.2 \%$ of their isolates, not alone but in combination with the presence of $c y t K$, $n h e$, and $h b l$ genes. As mentioned previously, food matrices affect the growth and toxin production of $B$. cereus and emetic syndrome usually occurs from starchy food products (MCKILLIP, 2000; AGATA et al., 2002; WALKER YORK MOORE et al., 2017). Interestingly, the $B$. cereus strains carrying the emetic toxin gene or having the ability to produce cereulide-like toxin have been isolated from raw milk and milk products (OWUSUKWARTENG et al., 2017), pasteurised milk (GAO et al., 2018), cooked meat (YU et al., 2020), and fish and fish products (WIJNANDS et al., 2006). However, according to AGATA et al. (2002), emetic toxin production was extremely low in such foods compared to bacterial growth.

\section{Analysis of genetic relationship by PFGE}

Using PFGE, three major patterns (A, B, C) were obtained with the macrorestriction enzyme SmaI among the $84 \mathrm{~B}$. cereus strains investigated. PFGE patterns $\mathrm{A}$ and $\mathrm{B}$ were both divided into two subgroups: $\mathrm{A}_{1}$ and $\mathrm{A}_{2}, \mathrm{~B}_{1}$ and $\mathrm{B}_{2}$, whereas PFGE pattern $\mathrm{C}$ generated only one group. PFGE patterns $\mathrm{B}, \mathrm{A}$, and $\mathrm{C}$ consisted of eight (9.5\%), $14(16.6 \%)$, and 62 (73.8\%) B. cereus strains, respectively. To compare clonality, a high genetic relationship between the isolates was detected at the 92\% similarity level (Figure 2).

Molecular-based techniques such as PFGE, multi-locus sequence typing (MLST), and enterobacterial repetitive intergenic consensus-PCR (ERIC-PCR) are widely used for bacterial typing, revealing the genetic relationship or genetic diversity. When we analysed our isolates by PFGE, we observed a high genetic relationship between them, and three major PFGE pulsotype profiles were obtained. Unlike our study, LIU et al. (2016), GAO et al. (2018), PARK et al. (2009), and SÁNCHEZ-CHICA et al. (2020a) reported high numbers of pulsotypes using PFGE and ERIC-PCR typing, indicating that there was high genetic diversity among their isolates. GDOURABEN AMOR et al. (2018) found that $33.3 \%$ of their isolates were divided into 27 different clusters while the remainder were clustered individually. In another study, large genetic diversity was observed in Colombia among $46 \mathrm{~B}$. cereus isolates recovered from powdered food samples that were grouped in seven clusters (SÁNCHEZ-CHICA et al., 2020b). In China, when YU et al. (2020) detected the genetic diversity of $B$. cereus isolates by MLST, 192 different sequence types were obtained, and 93 of them were new. In this respect, we can say that molecular typing methods can help us better understand the molecular epidemiology of $B$. cereus strains. Conversely, PFGE has been accepted as the gold standard for the discrimination and molecular characterisation of bacterial strains. In addition, using more than one restriction enzyme in PFGE analysis could increase the discriminatory power of the method, but we used only one restriction enzyme (Smal) in the present study. 


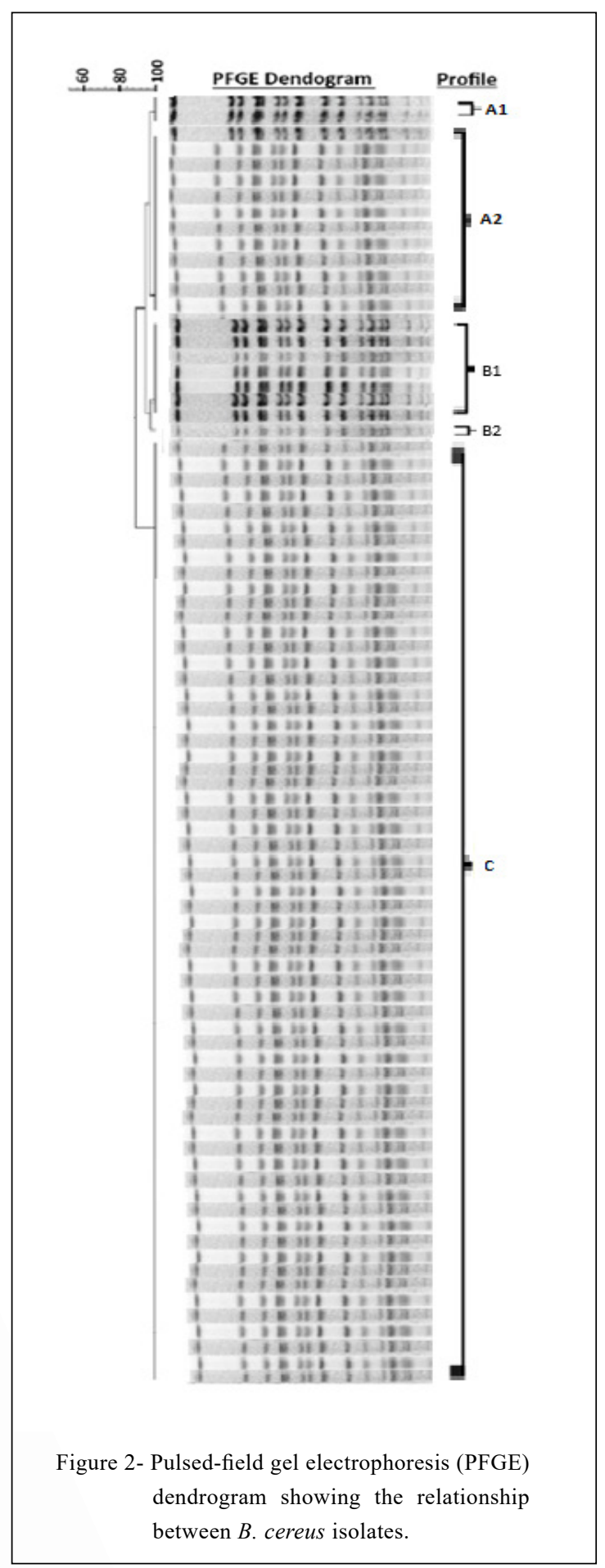

\section{CONCLUSION}

Our results indicated that the tested foods were frequently contaminated with $B$. cereus and that $31 \%$ of the $B$. cereus strains were both psychrotrophic and enterotoxigenic, which may increase the potential risk for both food spoilage and food poisoning. In addition, most of the isolated strains show similar PFGE patterns indicating that there is a high genetic relationship between them. As a high genetic relationship was detected between our isolates from different samples, cross-contamination of samples with these bacteria may be considered. This study was conducted in a specific region where local people consume a great many of these products. The study reveals the potential sources of $B$. cereus and provides a scientific basis for further investigation. Of course, more studies should be carried out to better understand the virulence mechanism and molecular epidemiology of B. cereus strains.

\section{DECLARATION OF CONFLICT OF INTERESTS}

The authors declare no conflict of interest.

\section{AUTHORS' CONTRIBUTIONS}

The authors contributed equally to the manuscript.

\section{ACKNOWLEDGEMENTS}

Part of this study was presented at the VIII National/ II International Veterinary Food Hygiene Congress, 24-27 October 2019, Antalya, Turkey.

\section{REFERENCES}

ADAME-GÓMEZ, R. et al. Prevalence of the strains of Bacillus cereus group in artisanal Mexican cheese. Foodborne Pathogens and Disease, v.17, n.1, p.8-14, 2020. Available from: <https:// pubmed.ncbi.nlm.nih.gov/31532237/>. Accessed: Feb. 15, 2021. doi: 10.1089/fpd.2019.2673.

AGATA, N. et al. Production of Bacillus cereus emetic toxin (cereulide) in various foods. International Journal of Food Microbiology, v.73, n.1, p. 23-27, 2002. Available from: <https:// pubmed.ncbi.nlm.nih.gov/11883672/>. Accessed: Feb. 15, 2021. doi: 10.1016/s0168-1605(01)00692-4.

AKSU, H. et al. Presence of Bacillus cereus in packaged some spices and herbs sold in Istanbul. Pakistan Journal of Biological Sciences, v.3, n.5, p.710-712, 2000. Available from: <http:// docsdrive.com/pdfs/ansinet/pjbs/2000/710-712.pdf $>$. Accessed: Feb. 15, 2021.

BENAHMED, M. et al. Biodiversity, spoilage capacity and heat resistance of mesophilic aerobic spores isolated from milk powders marketed in Algeria. International Journal of Dairy Technology, v.73, n.4, p.771-780, 2020. Available from: <https:// onlinelibrary.wiley.com/doi/epdf/10.1111/1471-0307.12715>. Accessed: May. 5, 2021. doi: 10.1111/1471-0307.12715. 
BERTHOLD-PLUTA, A. et al. Prevalence and toxicity characterization of Bacillus cereus in food products from Poland Foods, v.8, n.7, p.269, 2019. Available from: <https://pubmed. ncbi.nlm.nih.gov/31331094/>. Accessed: Feb. 15, 2021. doi: $10.3390 /$ foods 8070269

CADIRCI, O. et al. Determination of enterotoxigenic gene profiles of Bacillus cereus strains isolated from dairy desserts by multiplex PCR. Kafkas Üniversitesi Veteriner Fakültesi Dergisi, v.19, n.5, p.869-874, 2013. Available from: <http://vetdergikafkas.org/ abstract.php?id=1413>. Accessed: Feb. 15, 2021. doi: 10.9775/ kvfd.2013.9008.

EHLING-SCHULZ, M. et al. Emetic toxin formation of Bacillus cereus is restricted to a single evolutionary lineage of closely related strains. Microbiology (Reading), v.151, p.183-197, 2005. Available from: <https://pubmed.ncbi.nlm.nih.gov/15632437/>. Accessed: Feb. 15, 2021. doi: 10.1099/mic.0.27607-0.

EHLING-SCHULZ, M. et al. Toxin gene profiling of enterotoxic and emetic Bacillus cereus. FEMS Microbiology Letters, v.260, n.2, p.232-240, 2006. Available from: <https://pubmed.ncbi.nlm. nih.gov/16842349/>. Accessed: Feb. 15, 2021. doi: 10.1111/j.15746968.2006.00320.x.

FOGELE, B. et al. Occurrence and diversity of Bacillus cereus and moulds in spices and herbs. Food Control, v.83, p.69-74, 2018. Available from: <https://www.sciencedirect.com/science/ article/pii/S0956713517302803 >. Accessed: May. 5, 2021. doi: 10.1016/j.foodcont.2017.05.038.

GAO, T., et al. Prevalence, virulence genes, antimicrobial susceptibility, and genetic diversity of Bacillus cereus isolated from pasteurized milk in China. Frontiers in Microbiology, v.9, 533, 2018. Available from: <https://pubmed.ncbi.nlm. nih.gov/29632521/>. Accessed: Feb. 15, 2021. doi: 10.3389/ fmicb.2018.00533.

GDOURA-BEN AMOR, M. et al. Isolation, identification, prevalence, and genetic diversity of Bacillus cereus group bacteria from different foodstuffs in Tunisia. Frontiers in Microbiology, v.9, 447, 2018. Available from: <https://pubmed.ncbi.nlm. nih.gov/29593691/>. Accessed: Feb. 15, 2021. doi: 10.3389/ fmicb.2018.00447.

GRANUM, P.E.; LUND, T. Bacillus cereus and its food poisoning toxins. FEMS Microbiology Letters, v.157, n.2, p.223-228, 1997. Available from: <https://doi.org/10.1111/j.1574-6968.1997. tb12776.x>. Accessed: Feb. 15, 2021.

GUNDOGAN, N.; AVCI, E. Occurrence and antibiotic resistance of Escherichia coli, Staphylococcus aureus and Bacillus cereus in raw milk and dairy products in Turkey. International Journal of Dairy Technology, v.67, n.4, p.562-569, 2014. Available from: <https:// onlinelibrary.wiley.com/doi/epdf/10.1111/1471-0307.12149>. Accessed: Feb. 15, 2021. doi: 10.1111/1471-0307.121.

HARIRAM, U.; LABBE, R. Spore prevalence and toxigenicity of Bacillus cereus and Bacillus thuringiensis isolates from U.S. retail spices. Journal of Food Protection, v.78, n.3, p.590596, 2015. Available from: <https://meridian.allenpress.com/ jfp/article/78/3/590/173805>. Accessed: May. 5, 2021. doi: 10.4315/0362-028X.JFP-14-380.

LIU, X. et al. Application of pulsed-field gel electrophoresis (PFGE) in Bacillus cereus typing. International Journal of
Clinical and Experimental Pathology, v. 9, n.9, p.9497-9502, 2016. Available from: <http://www.ijcep.com/files/ijcep0035673. pdf $>$. Accessed: Feb. 15, 2021.

MCKILLIP, J.L., Prevalence and expression of enterotoxins in Bacillus cereus and other Bacillus spp., a literature review. Antonie van Leeuwenhoek, v.77, p.393-399, 2000. Available from: $<$ https://link.springer.com/article/10.1023/A:1002706906154>. Accessed: Feb. 15, 2021. doi: 10.1023/A:1002706906154.

OSMAN, K.M. et al. Poultry and beef meat as potential seedbeds for antimicrobial resistant enterotoxigenic Bacillus species: a materializing epidemiological and potential severe health hazard. Scientific Reports, v.8, 11600, 2018. Available from: <https:// www.nature.com/articles/s41598-018-29932-3.pdf>. Accessed: Feb. 15, 2021. doi: 10.1038/s41598-018-29932-3.

OWUSU-KWARTENG, J. et al. Prevalence, virulence factor genes and antibiotic resistance of Bacillus cereus sensu lato isolated from dairy farms and traditional dairy products. BMC Microbiology, v.17, 65, 2017. Available from: <https://www.ncbi. nlm.nih.gov/pmc/articles/PMC5348786/>. Accessed: Feb. 15, 2021. doi: 10.1186/s12866-017-0975-9.

PARK, Y.B. et al. Prevalence, genetic diversity, and antibiotic susceptibility of Bacillus cereus strains isolated from rice and cereals collected in Korea. Journal of Food Protection, v.72, n.3, p.612-617, 2009. Available from: <https://pubmed.ncbi.nlm. nih.gov/19343952/>. Accessed: Feb. 15, 2021. doi: 10.4315/0362028x-72.3.612.

PRETORIUS, C.; BUYS, E. M. Extended shelf life milk processing: Effect of simulated cleaning in place on the germination and attachment of Bacillus cereus spores. International Journal of Dairy Technology, v.74, n.1, p.75-83, 2021. Available from: <https:// onlinelibrary.wiley.com/doi/epdf/10.1111/1471-0307.12744>. Accessed: May. 5, 2021. doi: 10.1111/1471-0307.12744.

SÁNCHEZ-CHICA, J. et al. Genomic and toxigenic heterogeneity of Bacillus cereus sensu lato isolated from ready-to-eat foods and powdered milk in day care centers in Colombia. Foodborne Pathogens and Disease, v.17, n.5, p.340-347, 2020a. Available from: < https://pubmed.ncbi.nlm.nih.gov/31738585/>. Accessed: Feb. 15, 2021. doi: 10.1089/fpd.2019.2709.

SÁNCHEZ-CHICA, J. et al. Genetic and toxigenic diversity of Bacillus cereus group isolated from powdered foods. Journal of Food Science and Technology, 2020b. Available from: $<\mathrm{https}: / /$ doi.org/10.1007/s13197-020-04700-2>. Accessed: Feb. 15, 2021.

SOUZA, C.M.O.C.C.; ABRANTES, S.M.P. Detection of enterotoxins produced by $B$. cereus through PCR analysis of ground and roasted coffee samples in Rio de Janeiro, Brazil. Ciência e Tecnologia de Alimentos, Campinas, v.31, n.2, p.443449, 2011. Available from: <https://www.scielo.br/pdf/cta/v31n2/ v31n2a25.pdf $>$. Accessed: Feb. 15, 2021. doi: 10.1590/S010120612011000200025.

STENFORS ARNESEN, L.P. et al. From soil to gut: Bacillus cereus and its food poisoning toxins. FEMS Microbiology Reviews, v.32, n.4, p.579-606, 2008. Available from: <https:// pubmed.ncbi.nlm.nih.gov/18422617/>. Accessed: Feb. 15, 2021. doi: 10.1111/j.1574-6976.2008.00112.x.

TALLENT, S.M. et al. Bacillus cereus. Chapter 14. Bacteriological Analytical Manual. 2012. Available from: $<$ https://www.fda.gov/ 
food/laboratory-methods-food/bam-chapter-14-bacillus-cereus $>$. Accessed: Feb. 15, 2021.

TEWARI, A. et al. Incidence and enterotoxigenic profile of Bacillus cereus in meat and meat products of Uttarakhand, India. Journal of Food Science and Technology, v.52, n.3, p.17961801, 2015. Available from: <https://www.ncbi.nlm.nih.gov/pmc/ articles/PMC4348265/>. Accessed: Feb. 15, 2021. doi: 10.1007/ s13197-013-1162-0.

WALKER-YORK-MOORE, L. et al. Characterization of enterotoxigenic Bacillus cereus sensu lato and Staphylococcus aureus isolates and associated enterotoxin production dynamics in milk or meat-based broth. Toxins, n.9, v.7, 225, 2017. Available from: <https:/www.ncbi.nlm.nih.gov/pmc/articles/ PMC5535172/>. Accessed: Feb. 15, 2021. doi: 10.3390/ toxins 9070225 .

WANG, R.F. et al.Auniversal protocol for PCR detection of 13 species of foodborne pathogens in foods. Journal of Applied Microbiology, v.83, p.727-736, 1997. Available from: < https://sfamjournals. onlinelibrary.wiley.com/doi/pdf/10.1046/j.1365-2672.1997.00300. $\mathrm{x}>$. Accessed: Feb. 15, 2021.

WIJNANDS, L.M. et al. Prevalence of potentially pathogenic Bacillus cereus in food commodities in the Netherlands. Journal of Food Protection, v.69, n.11, p.2587-2594, 2006. Available from: $<$ https://pubmed.ncbi.nlm.nih.gov/17133800/>. Accessed: Feb. 15, 2021. doi: 10.4315/0362-028x-69.11.2587.

YIBAR, A. et al. Prevalence, enterotoxin production and antibiotic resistance of Bacillus cereus isolated from milk and cheese. Kafkas Üniversitesi Veteriner Fakültesi Dergisi, v.23, n.4, p.635-642, 2017. Available from: <http://vetdergikafkas.org/uploads/pdf/ pdf_KVFD_L_2094.pdf>. Accessed: Feb. 15, 2021. doi: 10.9775/ kvfd. $2017 . \overline{17480}$

YU, S. et al. A study on prevalence and characterization of Bacillus cereus in ready-to-eat foods in China. Frontiers in Microbiology, v.10, 3043, 2020. Available from: <https://www.frontiersin.org/ articles/10.3389/fmicb.2019.03043/full>. Accessed: Feb. 15, 2021. doi:10.3389/fmicb.2019.03043. 